\title{
Exploration and Practice of New Talent Training Model on Military and Local Cooperation
}

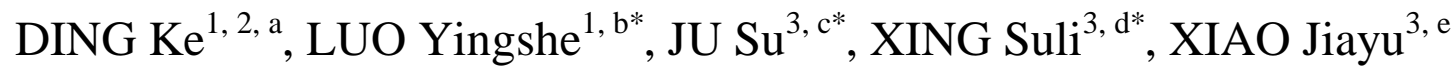 \\ ${ }^{1}$ Hunan Province Key Laboratory of Engineering Rheology, Central South University of Forestry and Technology, \\ Changsha, 410004, Hunan, China \\ ${ }^{2}$ College of Civil Engineering and Mechanics, Central South University of Forestry and Technology, Changsha, \\ 410004, Hunan, China \\ ${ }^{3}$ College of Aerospace Science and Engineering, National University of Defense Technology, Changsha 410073, \\ Hunan, China \\ akding@sina.com, ${ }^{\mathrm{b}}$ lys0258@sina.com, ${ }^{\mathrm{c}} 46163757 @ q q . c o m,{ }^{\mathrm{d}}$ xingsuli@sina.com , \\ e jiayuxiao@tom.com
}

Keywords: Military and regional cooperation; Training model; Exploration; Civil-military integration; Practice

\begin{abstract}
In the paper, the training model of high-level talents is discussed through the cooperation between military and common university. At first, the undergraduates in the common university finished the course learning outcomes and obtain the required credits. Then these undergraduates are sent to the related college or key laboratory in the military university and take the graduation thesis experimental. Under the union direction of teachers in military and common university, the undergraduates finish the graduation thesis and defend their disserations in the common university. The practice shows that the talents own the good scientific research ability and comprehensive qualities.
\end{abstract}

\section{Introduction}

With the development of science and socio-economy, social needs for high-level talents become increasingly strong. So country needs to strengthen the training of high-level talents. However, it is necessary to own the advanced teaching and research facilities and the good experimental conditions for training the high-level talents. Relatively speaking, the research environment in the military universities is better than the local universities [1]. And the academic atmosphere in the military universities is stronger. How to take advantage of the resource of the military universities to train the high-level talents for economic development is our research topic. We need to discuss and explore the effective way.

Usually, the military and regional cooperation at home and abroad mainly manifested in the change of direction of the national industrial base from the traditional civil-military separation to the civil-military integration. The military companies can manufacture the products for the armies and the local governments [2]. And the civil companies can also manufacture the products for the armies and the local governments. According to the above definition, the shared technology, methodology, labor, facilities and material can be used to meet the needs of defense and civilian needs [3].

With the rapid economic development and social progress and the continuous deepening of reform and opening, the model of military and local cooperation obtained continuous innovation and the cooperation field is expanded. For instance, an agreement was signed by Shanghai Municipal Government and the general staff of the People's Liberation Army in April 26, 2012. According to the agreement, National application of beidou industrial base was built in Shanghai. 
Therefore, whether four military schools (including the United States Military Academy at West Point, Royal Military Academy Sandhurst, Frunze Military Academy, École Spéciale Militaire de Saint-Cyr) abroad or military colleges in China, the news about training the high-level and high-quality talents through the model of military and regional cooperation have been rarely reported for long time [4].

It is no doubt that training the high-level and high-quality talents is the most basic through the model of military and regional cooperation. From a long-term point of view, the way of cooperation will be of great strategic importance.

\section{Talent training model of military and local cooperation}

Talent training concept of military and local cooperation. The talent training model of military and local cooperation mentioned in the paper is different from the national education which is traditionally introduced by military academies. The traditionally national education refers to the military academies recruit undergraduate and graduate students who don't wear uniforms and are not incorporated into force [5]. They obtain military academies enrollment and are awarded the military academy graduate degree. The high level talents mentioned in the paper refer that these undergraduate and graduate students finish course learning outcomes and obtain the prescribed credits in the local universities. Then they finish their graduation thesis experimental and write their graduation dissertation in the military academies. Their enrollment is still in the local universities.

The new talents for both military and civilian services are is different from the traditional talents which are introduced by military academies before. The traditional talents for both military and civilian services point to the People's liberation army cadres and fighters who are systematically trained for the military affairs, the political affairs, the culture, the physical performance and the civilian skills. They own two sets of skills of defending the motherland and production. And they play an important role in the army and local development. They are the socialist new man with ideals, moral integrity, education and a sense of discipline. Therefore the new talents for both military and civilian services mentioned in the paper are the excellent graduates in the local universities.

Talent training method of military and local cooperation. The undergraduate students in the local universities finish course learning outcomes and obtain the prescribed credits in their own universities. A cooperation agreement and non-disclosure agreement are signed by the relevant key laboratory between the local universities and the military academies. Then the undergraduate students in the local universities take advantage of the technology, advanced equipment, materials and research methods in the military academies.

Under the guidance of teachers from the local universities and the military academies, these students do scientific experiments with the related project in the key laboratory of the military academies. Then they finish their graduation dissertation and come back to the local universities to defend their thesis.

\section{Talent training significance of military and local cooperation}

Through close cooperation between local universities and military academies, the combined training of the high level talents is very important to enrich talents training mode and strengthen talents cultivation strategy in our country. The significance is mainly manifested in the following aspects.

At first, the talents training mode greatly benefit to learn from each other's strengths to offset their own weaknesses. Through the combined training of the high level talents, the teachers and students can learn from each other and exchange experience between local universities and military academies. In general, the military academies are known for their strict discipline. The students in military academies study hard and have the hard-working spirit. The local universities are more open. The students in local 
universities are more vibrant and own more space. Their sense of innovation is stronger. There is a lot to learn from each other and jointly improve.

Secondly, the talents training mode greatly benefit to share resource and complement each other's advantages. The country invests a lot of money to military academies for national defense and national security needs. So the military academies own the good infrastructure, laboratory and teaching \& research Platform. The hardware in the military academies is far superior to the local universities. On the other hand, the technology, equipment, materials and research methods are the same. Therefore, the local universities can take full advantage of the resources to train the high level talents. The training mode can avoid repeat construction and save money.

\section{Talent training practice of military and local cooperation}

In recent years, National University of Defense Technology and our university carry on a few collaborations for training of the high level talents. We obtained some experience and made some achievements. Table 1 shows the situation of talent training by military and local cooperation. In 2011, Tian Fang, which come from class 1 in 2007 grade engineering mechanics, finished her bachelor's degree thesis directed by Prof. Luo Yingshe coming from Central South University of Forestry and Technology (CSUFT) and Xing Suli coming from National University of Defense Technology (NUDT). Her paper, research on the influence of stress on dielectric strength of the fiber reinforced composites, was awarded the excellent thesis by CSUFT. Because of the good foundation, she has published several papers and obtained the National Scholarship during the graduate students. In 2014, she is accepted as a doctoral student at Tongji University. In 2015, Ouyang Heng was recommended to Hunan University for postgraduate student excellent performance. Li Yuguo and He Bin have been admitted to the graduate.

Table 1 The situation of talent training by military and local cooperation

\begin{tabular}{|c|c|l|}
\hline name & $\begin{array}{c}\text { date of } \\
\text { graduation }\end{array}$ & \multicolumn{1}{|c|}{ title } \\
\hline Zhu Guodong & 2010 & $\begin{array}{l}\text { China's production of carbon fiber reinforced composite } \\
\text { material of reinforced concrete beam specimen }\end{array}$ \\
\hline Wang Yichen & 2010 & $\begin{array}{l}\text { The research of the basic mechanical properties of } \\
\text { domestic carbon fiber }\end{array}$ \\
\hline Tian Fang & 2011 & $\begin{array}{l}\text { Research on the Influence of Stress on Dielectric Strength } \\
\text { of the Fiber Reinforced Composites }\end{array}$ \\
\hline Wang Yan & 2011 & $\begin{array}{l}\text { Flexural Property Investigation of The 3D Integrated } \\
\text { Composite Sandwich Structure }\end{array}$ \\
\hline Li & 2012 & $\begin{array}{l}\text { Preparation and Mechanical Property Investigation of } \\
\text { Glass Fiber Reinforced Epoxy Resin Composites }\end{array}$ \\
\hline Du Peijie & 2012 & $\begin{array}{l}\text { Simulation of the Deformation Behavior of PMI Foam } \\
\text { under Mechanical and Thermal Coupling Action }\end{array}$ \\
\hline Li Zhongyi & 2013 & $\begin{array}{l}\text { Study on surface modification of PBO fiber and its } \\
\text { interfacial properties with epoxy matrix }\end{array}$ \\
\hline Zhu Yanming & 2013 & $\begin{array}{l}\text { Manufacture and Performance of Composite Square Tube } \\
\text { in Spatial Structure }\end{array}$ \\
\hline Ouyang Heng & 2015 & $\begin{array}{l}\text { Influence of the elastic recovery effect on the mechanical } \\
\text { properties of the composite materials }\end{array}$ \\
\hline
\end{tabular}




\begin{tabular}{|c|c|l|}
\hline Li Yuguo & 2015 & $\begin{array}{l}\text { Study on the influence of the reduction reaction on the } \\
\text { mechanical properties of the oxide graphene films }\end{array}$ \\
\hline He Bin & 2015 & $\begin{array}{l}\text { Design and fabrication of the graphite fiber composite } \\
\text { pipe }\end{array}$ \\
\hline Li Juan & 2015 & $\begin{array}{l}\text { Fabrication and property study of the quartz and cyanate } \\
\text { ester resin composite materials }\end{array}$ \\
\hline
\end{tabular}

\section{Discussion}

At present, high technology is booming. And military and civilian technologies connect more and more closely. With the courses reform going deeper, our talent training model should appear a variety of forms which meet the demands of our domestic market. The talent training model on military and regional cooperation discussed in the paper is the new research subjects. In order to develop the diversified talent training mode, it is necessary to explore and practice constantly. Through our attempts in recent years, the practice shows that these talents which are trained by the model on military and regional cooperation own the good scientific research ability and comprehensive qualities.

\section{Acknowledgements}

The work supported by the teaching reform project of colleges and universities of Hunan Province (Xiang Jiao Tong [2013]223) and the project of Chinese Society of academic degrees and graduate education (2013Y08).

\section{References}

[1] Xu Jianjun, Zhou Yi. On cultivation of the general talents for both military and local use by taking advantage of national education resources [J]. Journal of North University of China (Social Science Edition), 2007, 23(4): 78-82

[2] Guo Qin, Liao Dongshen, Guo Jing. Research on the training mode of the military and civilian equipment technology talents [J]. Science \& Technology Progress and Policy, 2014, 31(3): $119-122$

[3] Chen Zhonghuai. Discussion on training compound talents of national defense in local universities[J]. Education Exploration, 2010, No. 7 : 75-76

[4] Wang Yuansheng, Chen Shiping, Lu Junling. Study on the army and local universities joint running modes in higher education [J]. Journal of Higher Education Research, 2001, 24(3): $31-34$

[5] Xun Chao, Chen Jian. Investigation and concept of the regional joint school-running of military academies and local institutions [J]. Journal of Higher Education Research, 2008, 31(4): 11-14

[6] Wu Junde, Wu Lidong. Some considerations on carrying out the joint cchool-running of military academies and local universities [J]. Journal of Shaannxi Normal University (Philosophy and Social Sciences Edition), 2004, 33(S): 121-122 